\title{
Tumor Necrosis Factor- $\alpha$ Mediates Changes in Tissue Protein Turnover in a Rat Cancer Cachexia Model
}

\author{
Paola Costelli, * Neus Carbó, " Luciana Tessitore, * Gregory J. Bagby," Francisco J. Lopez-Soriano, ${ }^{5}$ Josep M. Argilés, ${ }^{5}$ and \\ Francesco M. Baccino ** \\ * Dipartimento di Medicina ed Oncologia Sperimentale, Sezione di Patologia Generale, Università di Torino, and ${ }^{\ddagger}$ Centro Consiglio \\ Nazionale delle Ricerche di Immunogenetica ed Oncologia Sperimentale, 10125 Torino, Italy; ${ }^{\S}$ Departamento de Bioquimica y \\ Fisiologia, Universidad de Barcelona, 08071 Barcelona, Spain; 'Department of Physiology, Louisiana State University Medical Center, \\ New Orleans, Louisiana
}

\begin{abstract}
Rats bearing the Yoshida AH-130 ascites hepatoma showed enhanced fractional rates of protein degradation in gastrocnemius muscle, heart, and liver, while fractional synthesis rates were similar to those in non-tumor bearing rats. This hypercatabolic pattern was associated with marked perturbations of the hormonal homeostasis and presence of tumor necrosis factor in the circulation.

The daily administration of a goat anti-murine TNF IgG to tumor-bearing rats decreased protein degradation rates in skeletal muscle, heart, and liver as compared with tumor-bearing rats receiving a nonimmune goat IgG. The anti-TNF treatment was also effective in attenuating early perturbations in insulin and corticosterone homeostasis. Although these results suggest that tumor necrosis factor plays a significant role in mediating the changes in protein turnover and hormone levels elicited by tumor growth, the inability of such treatment to prevent a reduction in body weight implies that other mediators or tumorrelated events were also involved. (J. Clin. Invest. 1993. 92:2783-2789.) Key words: tumor necrosis factor • skeletal muscle $\bullet$ protein turnover $\bullet$ cachexia
\end{abstract}

\section{Introduction}

Loss of body weight and cachexia are common signs associated with neoplastic diseases. Cachexia is a poorly understood syndrome characterized by anorexia, profound metabolic abnormalities, and progressive host wasting that results in death (13 ). Tissue wasting mainly involves skeletal muscles and adipose tissue. Numerous reports attribute the development of the cachectic state to the release of cytokines, such as TNF (for a review, see reference 4 ).

TNF is primarily produced by activated macrophages in response to invasive stimuli. It belongs to a polypeptide network made up of several cytokines and growth factors that have wide and varied effects on the growth, differentiation, and functions of the immune system, as well as of other cells and tissues $(5,6)$. Chronic treatment of rats with recombinant

Address correspondence to Dr. Luciana Tessitore, Dipartimento di Medicina ed Oncologia Sperimentale, Sezione Patologia Generale, Corso Raffaello 30, 10125 Torino, Italy. 1993.

Received for publication 13 April 1993 and in revised form 7 June

J. Clin. Invest.

(C) The American Society for Clinical Investigation, Inc.

0021-9738/93/12/2783/07 \$2.00

Volume 92, December 1993, 2783-2789
TNF results in depletion of body protein, as compared with pair-fed control animals (7), and redistribution of body protein associated with significant muscle protein depletion and coordinated decreases in muscle mRNAs for myofibrillar proteins (8). The administration of recombinant TNF enhances the nitrogen efflux from skeletal muscle in non-weight losing humans with disseminated cancer (9), as well as muscle protein breakdown in rats $(10)$. In vitro proteolytic rates in muscles isolated from rats receiving a single dose of TNF have been reported either unchanged (11) or increased (12).

Rats bearing the ascites hepatoma Yoshida AH-130 offer a suitable model system for investigations into the mechanisms that lead to cancer cachexia. Previous work has shown that tumor growth rapidly elicits in the host rat a conspicuous body weight loss associated with a hypercatabolic state in tissue protein $(13,14)$. Marked perturbations in the hormonal homeostasis develop early after tumor implantation, together with increased levels of prostaglandin $\mathrm{E}_{2}$ and detectable TNF in plasma (15). It thus appeared of interest to explore the role played by TNF in this experimental model of cancer cachexia. The aim of the present investigation was to evaluate the involvement of this cytokine in mediating the changes in muscle protein turnover in AH-130 tumor-bearing rats through the administration of a goat polyclonal anti-murine TNF IgG. Such a treatment both abolished any detectable free TNF in the plasma and afforded a significant preservation of muscle protein, thus supporting a causative role for TNF as a mediator for cachexia in this experimental model.

\section{Methods}

Biochemicals. Sodium $\left[{ }^{14} \mathrm{C}\right]$ bicarbonate (specific activity $53 \mathrm{mCi} /$ $\mathrm{mmol}$ ) was obtained from Amersham (Braunschweig, Germany).

Animals, tumor, and anti-TNF treatment. Male Wistar rats (Charles River, Como, Italy) were fed ad libitum on a chow diet (Piccioni, Brescia, Italy) consisting by weight of $49 \%$ carbohydrate, $20 \%$ protein, and $5 \%$ fat (the residue was nondigestible material). Animals had free access to drinking water and were maintained at an ambient temperature of $22^{\circ} \mathrm{C}$ under a 12-h light / 12-h dark cycle (light on from 08:00 h).

A suspension of Yoshida AH-130 ascites hepatoma cells $\left(\sim 10^{8}\right.$ in $2 \mathrm{ml}$ ) was injected intraperitoneally ( $\mathrm{cf} 13$ ), while the control rats received $2 \mathrm{ml}$ of $0.9 \%$ (wt/vol) $\mathrm{NaCl}$ solution. Food intake and body weight were measured daily after tumor inoculation.

Tumor-bearing animals either received no treatment or were given daily $(09: 00 \mathrm{~h})$ subcutaneous injections of $25 \mathrm{mg} / \mathrm{kg}$ body wt of a polyclonal goat anti-murine TNF IgG preparation (anti-TNF) or of a nonimmune goat $\mathrm{IgG}$ preparation ( $\mathrm{IgG})$. Treatments started the day after tumor transplantation and lasted $6 \mathrm{~d}$. No significant differences were observed in the daily food intake among untreated animals, or rats receiving nonimmune IgGs or anti-TNF IgGs.

Polyclonal goat anti-murine TNF IgGs were prepared using the Ribi adjuvant system containing $0.5 \mathrm{mg}$ each of monophosphoryl lipid 
A, trehalose dimycolate, and cell wall skeleton in $0.2 \%$ Tween 80 ( Ribi ImmunoChem. Res., Inc., Hamilton, MT). The serum IgG fraction was obtained by polyethylene glycol precipitation and column chromatography with DEAE Bio-Gel A (Bio-Rad Laboratories, Richmond, CA). The neutralizing capacity of the anti-TNF IgG fraction in the L929 cytotoxicity assay was 6.5 and $9.0 \times 10^{5} 50 \%$ neutralizing units/ $\mathrm{mg}$ IgG against recombinant $\mu \mathrm{TNF}-\alpha$ and serum TNF from LPStreated rats, respectively. Nonimmune goat IgGs were prepared in the same way and had no detectable TNF neutralizing activity (16). Neither IgG preparation demonstrated effective binding to LPS, IL-1, or interferon- $\gamma$ in an ELISA protocol.

Plasma metabolites. Circulating insulin and corticosterone were determined using the insulin (Corning Inc., Medfield, MA) and the rat corticosterone (IDS, Boldon, England) radioimmunoassay kits, respectively. Plasma TNF was measured using both the L929 cytotoxicity assay (17) and an ELISA test (Genzyme Corp., Cambridge, MA). Anti-TNF titers were estimated using an ELISA test (16).

Tissue protein turnover. In vivo protein turnover was determined as previously described (13). For this purpose, animals were injected intraperitoneally with $400 \mu \mathrm{Ci} / \mathrm{kg}$ body wt with $\mathrm{NaH}^{14} \mathrm{CO}_{3}$, dissolved in $0.15 \mathrm{M} \mathrm{NaCl}, 24 \mathrm{~h}$ before time 0 , and killed on days 0,4 , and 7 after tumor inoculation. Liver, kidneys, gastrocnemius, and heart were rapidly weighed and homogenized to $10 \%$ (wt/vol) in chilled water and then frozen to $-20^{\circ} \mathrm{C}$. Total protein content was determined by the method of Lowry et al. (18). Trichloroacetic acid-insoluble proteins were processed for lipid extraction, extensively hydrolyzed, and counted in a liquid scintillation spectrometer (cf 13). Total and specific (per milligrams of protein) protein radioactivity were determined for gastrocnemius muscle, heart, kidneys, and liver. Fractional rates of protein synthesis $\left(k_{\mathrm{s}}\right)$, protein degradation $\left(k_{\mathrm{d}}\right)$, and protein accumulation $\left(k_{\mathrm{a}}\right)$ were calculated $(19,20)$ by the following equations:

$$
\begin{aligned}
& k_{\mathrm{s}}=\ln \left(\text { specific protein radioactivity) } t^{-1}\right. \\
& k_{\mathrm{d}}=\ln \left(\text { total protein radioactivity) } t^{-1}\right. \\
& k_{\mathrm{a}}=\ln (\text { total protein }) t^{-1} \\
& k_{\mathrm{a}^{\prime}}=k_{\mathrm{s}}-k_{\mathrm{d}}
\end{aligned}
$$

and expressed as percent per day, while $t_{1 / 2}\left(=\ln 2 / k_{\mathrm{d}}\right)$ was given in days. The procedure adopted in studying protein radioactivity decay, with time 0 corresponding to $24 \mathrm{~h}$ after administration of the label, only takes into account the long-lived pool of tissue proteins, which represents the large majority of the protein mass.

Data presentation. Data are means \pm SEM. Significance of the differences was calculated by analysis of variance.

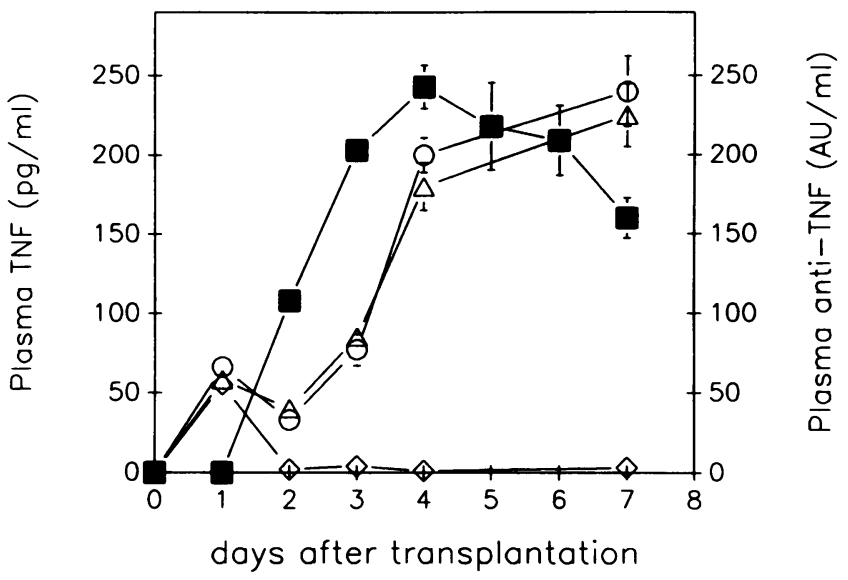

Figure 1. Plasma TNF and anti-TNF levels in AH-130 tumor-bearing rats. Anti-TNF titers ( $\square)$. TNF levels in untreated $(O)$, nonimmune IgGs $(\Delta)$, or anti-TNF-treated tumor hosts $(\diamond)$. Data are means $\pm \operatorname{SEM}(n=3-6)$.

\section{Results}

Tumor growth and body weight. The Yoshida AH-130 ascites hepatoma is a fast growing tumor: after an inoculum of $10^{8}$ cells, the growth was exponential for $4-5 \mathrm{~d}$ with a population doubling time of $23 \mathrm{~h}$, followed by a stationary phase from day 7 until death of the animals ( $\operatorname{cf} 13$ ). By day 4 after inoculation, the tumor-bearing rats exhibited a diminished gain in body weight, and by day 7 , their body weights were less than their initial body weights (Table I). During this period, there was a progressive increase in tumor volume (Table I). The anti-TNF treatment did not significantly affect such changes.

The tumor mass ( total cell wet weight) represented only 2.0 and $4.7 \%$ of host body weight on days 4 and 7 , respectively. Thus, changes in body weight can not be explained by growth of tumor mass by itself. The number of tumor cells was moderately decreased on day 4 in anti-TNF-treated animals, but this effect was transient and not present on day 7 (Table I).

\begin{tabular}{|c|c|c|c|c|c|}
\hline \multirow[b]{2}{*}{ Time } & \multirow[b]{2}{*}{ Treatment } & \multicolumn{2}{|c|}{ Body wt } & \multicolumn{2}{|c|}{ Tumor } \\
\hline & & Initial & Final & Volume & Cells $\times 10^{-6}$ \\
\hline \multicolumn{6}{|c|}{$g$} \\
\hline \multicolumn{6}{|l|}{ Day 4} \\
\hline Controls & None (3) & $167 \pm 2$ & $193 \pm 5$ & & \\
\hline \multirow[t]{3}{*}{ Tumor bearers } & None (7) & $167 \pm 3$ & $179 \pm 4$ & $15 \pm 2$ & $2,309 \pm 76$ \\
\hline & $\operatorname{IgG}(4)$ & $163 \pm 5$ & $172 \pm 5$ & $17 \pm 3$ & $2,151 \pm 157$ \\
\hline & Anti-TNF (3) & $164 \pm 2$ & $173 \pm 4$ & $14 \pm 5$ & $1,747 \pm 241^{*}$ \\
\hline \multicolumn{6}{|l|}{ Day 7} \\
\hline Controls & None (3) & $167 \pm 2$ & $228 \pm 1$ & & \\
\hline \multirow[t]{3}{*}{ Tumor bearers } & None (6) & $166 \pm 4$ & $148 \pm 5$ & $54 \pm 7$ & $4,682 \pm 157$ \\
\hline & $\operatorname{IgG}(3)$ & $165 \pm 6$ & $151 \pm 6$ & $51 \pm 1$ & $4,188 \pm 320$ \\
\hline & Anti-TNF (5) & $165 \pm 5$ & $154 \pm 6$ & $54 \pm 6$ & $5,001 \pm 200$ \\
\hline
\end{tabular}

Anti-TNF titer, TNF level, and plasma hormones. AntiTNF antibodies and TNF were measured in the plasma and

Table I. Body Weight and AH-130 Tumor Volume and Cellularity

Body weight is exclusive of tumor weight. Data are means \pm SEM for the number of animals given in parentheses. Significance of differences: ${ }^{*} P$ $<0.05$ vs untreated tumor bearers. 


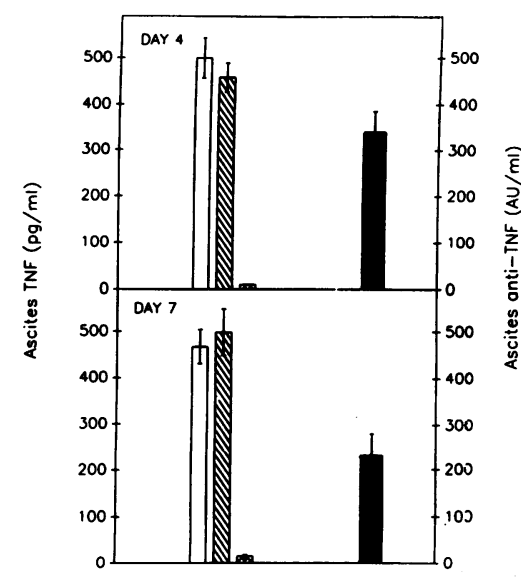

Figure 2. TNF and anti-TNF levels in the ascitic fluid of $\mathrm{AH}-130$ hosts. Anti-TNF titers (घ). TNF levels in untreated (ם), nonimmune IgGs $(\mathbb{\otimes})$, or antiTNF treated tumor hosts ( $\square)$. Data are means $\pm \operatorname{SEM}(n=3-6)$.

ascitic fluid of tumor-bearing animals given a daily dose of anti-TNF IgG, saline, or nonimmune IgG from 1 to $7 \mathrm{~d}$ after tumor transplantation. Plasma anti-TNF IgG (Fig. 1) remained steady between days 3 and 7, while their titer was somewhat higher in the ascitic fluid (Fig. 2). TNF (Fig. 1) was detectable in the serum of untreated tumor bearers after the first day of tumor transplantation and progressively increased during the tumor $\log$ growth phase. After day 4, levels stabilized regardless of the tumor burden or proliferative state, as noted previously (15). In the ascitic fluid TNF attained levels 53-60\% higher than in serum (Fig. 2), as one would expect if it was mainly produced intraperitoneally ( $\mathrm{cf} 15$ ). The administration of anti-TNF antibodies abolished any detectable free TNF in both serum (Fig. 1) and ascitic fluid (Fig. 2), while nonimmune IgGs had no effect.

Plasma insulin decreased while corticosterone increased in response to tumor growth (Fig. 3), in agreement with previous

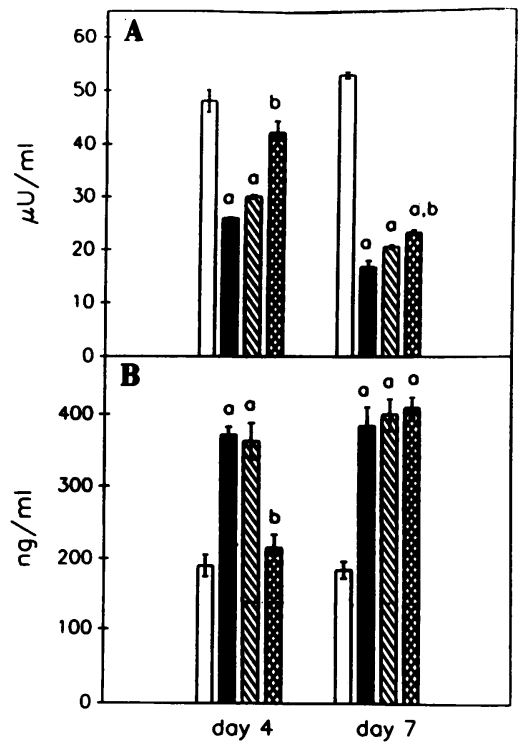

Figure 3. Blood plasma levels of insulin $(A)$ and corticosterone $(B)$.

Data are means \pm SEM $(n=3-6)$ in controls () and in AH-130 hosts either untreated $(\bullet)$ or treated with nonimmune $\operatorname{IgGs}(\mathbb{\otimes})$, and anti-TNF antibodies (匹). Significance of the differences: $a=P$ $<0.01$ vs controls; $b$ $=P<0.05$ anti-TNF treated AH- 130 hosts vs untreated or IgGs treated groups.

observations (15). Treatment with anti-TNF antibodies prevented the tumor-induced alterations on day 4 , but by day 7 , only insulin was still slightly higher than in nonimmune IgGtreated animals, while corticosterone did not differ between the three groups of animals.

Tissue wet weight and protein content. Tissue wet weight and protein data (Table II) are referred to $100 \mathrm{~g}$ of initial body weight for the purpose of standardization ( $\mathrm{cf} 20$ ). The gastrocnemius protein mass and wet weight were considerably compromized by tumor growth and the anti-TNF treatment significantly improved these parameters on both days 4 and 7, although the values still remained lower than in nontumor

Table II. Tissue Weight and Protein in AH-130 Tumor-bearing Rats

\begin{tabular}{|c|c|c|c|c|c|c|c|c|}
\hline \multirow[b]{3}{*}{ Tissue } & \multicolumn{4}{|c|}{ Day 4} & \multicolumn{4}{|c|}{ Day 7} \\
\hline & \multirow[b]{2}{*}{ Controls } & \multicolumn{3}{|c|}{ Tumor bearers } & \multirow[b]{2}{*}{ Controls } & \multicolumn{3}{|c|}{ Tumor bearers } \\
\hline & & None & $\lg G$ & Anti-TNF & & None & IgG & Anti-TNF \\
\hline \multirow[t]{2}{*}{ Muscle } & $631 \pm 9$ & $509 \pm 12$ & $516 \pm 22$ & $558 \pm 9$ & $660 \pm 17$ & $476 \pm 22$ & $483 \pm 21$ & $567 \pm 26$ \\
\hline & (3) & $* *(7)$ & $* *(3)$ & $* *(4)^{\ddagger}$ & (3) & $* *(6)$ & $* *(3)$ & $*(5)^{\ddagger}$ \\
\hline \multirow[t]{2}{*}{ Protein } & $59.4 \pm 0.9$ & $47.4 \pm 2.5$ & $51.3 \pm 1.5$ & $52.8 \pm 1.1$ & $64.5 \pm 0.7$ & $39.2 \pm 3.1$ & $40.3 \pm 1.4$ & $53.2 \pm 2.3$ \\
\hline & (3) & $*(7)$ & $* *(4)$ & $* *(3)$ & (3) & $* *(6)$ & $* *(3)$ & $(4)^{\ddagger * * \S}$ \\
\hline \multirow[t]{2}{*}{ Heart } & $395 \pm 18$ & $324 \pm 11$ & $305 \pm 10$ & $303 \pm 8$ & $391 \pm 9$ & $255 \pm 7$ & $249 \pm 13$ & $248 \pm 14$ \\
\hline & (3) & $* *(7)$ & $* *(3)$ & $* *(4)$ & (3) & $* *(6)$ & $* *(3)$ & $* *(5)$ \\
\hline \multirow[t]{2}{*}{ Protein } & $47.3 \pm 3.7$ & $37.6 \pm 3.0$ & $45.7 \pm 1.7$ & $50.0 \pm 2.6$ & $50.4 \pm 3.0$ & $32.6 \pm 3.2$ & $42.9 \pm 1.3$ & $41.7 \pm 0.9$ \\
\hline & (3) & $* *(5)$ & $(4)^{\ddagger \ddagger}$ & $(4)^{\ddagger \ddagger}$ & (3) & ${ }^{* *}(6)$ & (3) & $*(4)^{\ddagger}$ \\
\hline \multirow[t]{2}{*}{ Liver } & $5,532 \pm 94$ & $4,898 \pm 157$ & $4,910 \pm 123$ & $4,773 \pm 235$ & $6,711 \pm 11$ & $4,411 \pm 100$ & $4,776 \pm 174$ & $5,234 \pm 252$ \\
\hline & (3) & $*(7)$ & $*(3)$ & $*(3)$ & (3) & $* *(6)$ & $* *(3)$ & $* *(5)^{\ddagger \ddagger}$ \\
\hline \multirow[t]{2}{*}{ Protein } & $1,132 \pm 12$ & $898 \pm 27$ & $942 \pm 43$ & $894 \pm 27$ & $1,432 \pm 43$ & $865 \pm 19$ & $932 \pm 14$ & $988 \pm 73$ \\
\hline & (3) & $* *(5)$ & $*(4)$ & $* *(4)$ & (3) & $* *(6)$ & $* *(3)$ & $* *(5)$ \\
\hline \multirow[t]{2}{*}{ Kidney } & $1,008 \pm 47$ & $880 \pm 13$ & $841 \pm 18$ & $820 \pm 40$ & $1,124 \pm 36$ & $742 \pm 12$ & $811 \pm 23$ & $793 \pm 34$ \\
\hline & (3) & $*(7)$ & $*(3)$ & $*(4)$ & (3) & $* *(6)$ & $* *(3)^{\ddagger}$ & $* *(5)$ \\
\hline \multirow[t]{2}{*}{ Protein } & $246 \pm 18$ & $198 \pm 8$ & $199 \pm 7$ & $191 \pm 10$ & $277 \pm 21$ & $170 \pm 11$ & $173 \pm 13$ & $178 \pm 14$ \\
\hline & (3) & $* *(7)$ & $* *(3)$ & $* *(4)$ & (3) & $* *(6)$ & $* *(3)$ & $* *(5)$ \\
\hline
\end{tabular}

Data are means \pm SEM for the number of animals indicated in parentheses. Tissue wet weight and total protein expressed as milligrams per $100 \mathrm{~g}$ initial body wt. Statistical significance of the differences: * tumor bearers vs controls (untreated non-tumor bearers); ${ }^{\ddagger}$ nonimmune IgG- or anti-TNF-treated vs untreated tumor bearers; ${ }^{\S}$ nonimmune IgG vs anti-TNF treatment. ${ }^{* \ddagger} P<0.05 ;{ }^{* * \ddagger \ddagger \S} P<0.01$. 
bearers. Heart wet weight and protein content, both sharply decreased in untreated tumor bearers, were partially restored by treatment with anti-TNF, as well as with nonimmune IgGs on day 4 after transplantation, while only the former treatment was still effective on day 7 (Table II). Wet weight and protein content of liver and kidney decreased in tumor hosts, and the anti-TNF treatment did not induce any significant change in these parameters with respect to nonimmune IgG-treated animals.

Tissue protein turnover. To evaluate the effects of tumor growth and anti-TNF treatment on tissue protein turnover, AH-130 tumor-bearing animals were given a single dose of $\mathrm{NaH}^{14} \mathrm{CO}_{3} 24 \mathrm{~h}$ before tumor transplantation, then the total and specific radioactivity, as well as the total content of tissue protein, were measured on days 0,4 , and 7 of tumor growth (a detailed analysis of this procedure has been presented elsewhere: reference 13). A single radioactive precursor was used for all of the tissues investigated. This in vivo protein labeling technique is most suitable for liver (21), but is limited by recycling in skeletal muscle (22). However, fractional rates of pro- tein accumulation obtained by difference between fractional rates of synthesis and degradation $\left(k_{\mathrm{a}^{\prime}}=k_{\mathrm{s}}-k_{\mathrm{d}}\right)$ usually approximately match those calculated directly from changes in total protein $\left(k_{\mathrm{a}}\right)$, as shown in Table III. The 24-h lag between the administration of $\mathrm{NaH}^{14} \mathrm{CO}_{3}$ and the first experimental time (day 0 of tumor growth) was adequate to exclude from measurements the fast turnover protein pool, as well as secretory proteins; thus, this experimental protocol only evaluates the slow-turnover protein pool(s) (13). The protein turnover rates and the $t_{1 / 2}$ measured over the two observation windows (days 0-4 and days 4-7, respectively) were quite different for liver and kidney because of the heterogeneous half-lives of proteins of the slow turnover pool(s) (cf 23), while they were practically identical for muscle and heart; therefore, only data for the $0-7-d$ interval are presented for skeletal muscle and heart.

The effects of the anti-TNF treatment on protein synthesis and degradation in muscle and other tissues of tumor bearers are summarized in Table III. The skeletal muscle, which represents the major protein mass, was markedly affected in AH-130

Table III. Effect of Anti-TNF Treatment on Tissue Protein Turnover in AH-130 Tumor-bearing Rats

\begin{tabular}{|c|c|c|c|c|c|c|}
\hline Treatment & Days & $k_{\mathrm{s}}$ & $k_{\mathrm{d}}$ & $k_{\mathrm{a}}$ & $k_{\mathbf{a}^{\prime}}$ & $t_{1 / 2}$ \\
\hline \multicolumn{7}{|l|}{ Muscle } \\
\hline Controls & $0-7$ & 11.60 & 5.63 & 5.14 & 5.97 & 12.31 \\
\hline \multicolumn{7}{|l|}{ AH- 130 hosts } \\
\hline None & $0-7$ & 12.01 & 13.86 & -1.97 & -1.85 & 5.00 \\
\hline $\mathrm{IgG}$ & $0-7$ & 11.91 & 13.02 & -1.58 & -1.11 & 5.32 \\
\hline Anti-TNF & $0-7$ & 11.34 & 8.18 & 2.39 & 3.16 & 8.47 \\
\hline \multicolumn{7}{|l|}{ Heart } \\
\hline Controls & $0-7$ & 6.92 & 4.96 & 2.13 & 1.81 & 13.97 \\
\hline \multicolumn{7}{|l|}{ AH- 130 hosts } \\
\hline None & $0-7$ & 5.99 & 12.98 & -4.09 & -6.99 & 5.34 \\
\hline IgG & $0-7$ & 6.84 & 9.86 & -0.17 & -3.02 & 7.03 \\
\hline Anti-TNF & $0-7$ & 6.32 & 9.75 & -0.57 & -3.43 & 7.11 \\
\hline \multicolumn{7}{|l|}{ Liver } \\
\hline \multirow[t]{2}{*}{ Controls } & $0-4$ & 27.57 & 20.18 & 7.82 & 7.39 & 3.43 \\
\hline & $4-7$ & 15.77 & 13.02 & 7.83 & 2.57 & 5.32 \\
\hline \multicolumn{7}{|l|}{ AH-130 hosts } \\
\hline \multirow[t]{2}{*}{ None } & $0-4$ & 30.92 & 26.84 & 2.03 & 4.08 & 2.58 \\
\hline & $4-7$ & 13.62 & 20.36 & -1.25 & -6.74 & 3.40 \\
\hline \multirow[t]{2}{*}{ IgG } & $0-4$ & 31.17 & 27.06 & 3.22 & 4.11 & 2.56 \\
\hline & $4-7$ & 15.35 & 17.08 & -0.05 & -1.73 & 4.06 \\
\hline \multirow[t]{2}{*}{ Anti-TNF } & $0-4$ & 24.76 & 20.73 & 1.92 & 4.03 & 3.34 \\
\hline & $4-7$ & 11.86 & 10.77 & 3.33 & 1.09 & 5.84 \\
\hline \multicolumn{7}{|l|}{ Kidney } \\
\hline \multirow[t]{2}{*}{ Controls } & $0-4$ & 23.33 & 19.27 & 4.19 & 4.06 & 3.60 \\
\hline & $4-7$ & 11.95 & 8.44 & 3.95 & 3.51 & 8.22 \\
\hline \multicolumn{7}{|l|}{ AH- 130 hosts } \\
\hline \multirow[t]{2}{*}{ None } & $0-4$ & 23.55 & 24.96 & -1.23 & -1.41 & 2.78 \\
\hline & $4-7$ & 8.95 & 12.06 & -5.08 & -3.11 & 5.77 \\
\hline \multirow[t]{2}{*}{ IgG } & $0-4$ & 22.25 & 24.86 & -1.11 & -2.61 & 2.79 \\
\hline & $4-7$ & 8.60 & 11.39 & -4.67 & -2.79 & 6.09 \\
\hline \multirow[t]{2}{*}{ Anti-TNF } & $0-4$ & 19.61 & 21.86 & -2.13 & -2.26 & 3.17 \\
\hline & $4-7$ & 9.61 & 10.26 & -2.35 & -0.65 & 6.77 \\
\hline
\end{tabular}

Rates of protein synthesis $\left(k_{\mathrm{s}}\right)$, degradation $\left(k_{\mathrm{d}}\right)$, and accumulation $\left(k_{\mathrm{a}}^{\prime}, k_{\mathrm{a}}\right)$ expressed as percent per day, $t_{1 / 2}$ in days, and assessed on the 0-7$\mathrm{d}$ interval for gastrocnemius and heart or $0-4-$ and 4-7-d intervals for liver and kidneys. $k_{\mathrm{s}}$ and $k_{\mathrm{d}}$ calculated from the decay of specific and total protein radioactivity (means of three to seven data per ech time point, with SEM usually within $10 \%$ of the mean) after labeling with $\mathrm{NaH}^{14} \mathrm{CO}_{3}$, $k_{\mathrm{a}}$ from changes in total protein, while $k_{\mathrm{a}},=k_{\mathrm{s}}-k_{\mathrm{d}}$. For further details, see Methods. 
tumor-bearing rats. Protein waste implies an imbalance between synthesis and degradation. While the fractional synthesis rates $\left(k_{\mathrm{s}}\right)$ showed little change in the gastrocnemius and heart as a result of tumor growth, fractional rates of protein degradation $\left(k_{\mathrm{d}}\right)$ were markedly elevated, viz, 2.5-fold for gastrocnemius and 2.6-fold for heart, thus protein losses $\left(k_{\mathrm{a}}\right.$, and $\left.k_{\mathrm{a}}\right)$ in both tissues have to be mostly accounted for by the latter change. The anti-TNF treatment decreased protein degradation in the gastrocnemius, as compared with the animals receiving nonimmune IgGs and, as a result, protein accumulation was improved, although the values were still lower than in non-tumor bearers. Surprisingly, anti-TNF antibody and nonimmune IgGs had similar effects in slowing down protein degradation and improving protein accumulation in the heart.

In the liver, a slight increase in synthesis rates and an important increment in degradation rates were observed for both 0-4-d and 4-7-d intervals after tumor transplantation; consequently, the hepatic protein mass was markedly affected. The anti-TNF treatment decreased both synthesis and degradation rates to a similar degree in the first interval (0-4 d) so that protein loss was not evident. The anti-TNF treatment produced a marked reduction in protein degradation in the second observation period (4-7 d) to rates that were not different from those measured in non-tumor bearing controls. Liver protein was thus significantly preserved. Similar results occurred in the kidneys, but the effects of the anti-TNF treatment were less pronounced in this tissue.

\section{Discussion}

TNF has been proposed as an important mediator of cachexia $(4,5,24,25)$. Its role in cancer cachexia has been very controversial. No significant correlation was observed between severity of weight loss and serum TNF levels in cachectic patients (26). When given repeated injections of TNF, experimental animals develop tachyphylaxis, i.e., become progressively desensitised to the anorectic/cachectic action of the cytokine, and increasing daily doses of TNF are required to maintain the same effects (7). This phenomenon does not occur, however, if TNF is given by continuous infusion rather than by sporadic injections (27) or in nude mice implanted with Chinese hamster ovary cells transfected with the human TNF gene, which thus develop a profound cachectic state (28).

The ascites hepatoma Yoshida AH-130 causes early and progressive tissue waste in the host rats, by producing an unbalance in protein turnover towards the catabolic side (13). Such a pattern is associated with marked alterations in the hormonal homeostasis and occurrence of persistent TNF levels in the circulation (15). The present paper shows that administration of anti-TNF antibodies to these rats neutralized circulating TNF, thus making this a particularly interesting model to examine its possible involvement in cancer cachexia. A note of caution is suggested by the observation that the anti-TNF treatment resulted in a transient, slight reduction in the tumor cell number $4 \mathrm{~d}$ after transplantation. Whether this reflected the decreased availability of TNF as a possible autocrine growth factor for these tumor cells ( $\mathrm{cf} 15$ ) or a diminished availability of nutrients ( $\mathrm{cf} 29$ ) caused by the anticatabolic effects of the anti-TNF treatment or some other mechanism, it is difficult to establish at the moment. However, the observed reduction in tumor size on the one hand was too small to have exerted any significant effect on host metabolism ( $\mathrm{cf} 13$ ), on the other was quickly overcome and no longer detectable on day 7 of tumor growth.

In a another paper (Carbó, N., P. Costelli, L. Tessitore, G. J. Bagby, F. J. Lopez-Soriano, F. M. Baccino, and J. M. Argilés, submitted for publication ), we have shown that treatment with anti-TNF antibody significantly interfered with the development of perturbations of lipid metabolism and adipose tissue waste in AH-130 tumor-bearing rats. The present observations further show that treating the $\mathrm{AH}-130$ tumor-bearing animals with anti-TNF antibody had appreciable effects on protein turnover in all of the tissues examined, namely, gastrocnemius, heart, liver, and kidney. In general, the anti-TNF treatment was adequate to decrease the enhanced rates of protein degradation. By contrast, synthesis rates were little or negligibly affected by tumor growth and the anti-TNF treatment did not introduce any change, except in the liver, wherein a decrease in the synthesis rate was observed. Although not detected in the present experiments, likely because of the single time point selected (day 4), a transient enlargement of the liver during the very first days of AH-130 tumor growth is usually observed: a change associated with enhanced protein synthesis (13). This may reflect, in part at least, an acute phase reaction (see below). The reduction in hepatic protein synthesis afforded by the anti-TNF treatment may thus correspond to an interference with the late stages of such changes. In spite of the improved protein turnover patterns observed in all tissues examined, only the gastrocnemius benefitted with a significant preservation of protein mass by the anti-TNF treatment in comparison with untreated or nonimmune IgG-treated tumor bearers. Moreover, the anti-TNF treatment did not afford any significant preservation of the body and carcass weight. Although the present data do not provide any clue to account for this apparently paradoxical finding, a decreased water retention in anti-TNF-treated rats seems a likely explanation ( $\mathrm{cf} 7$, $24,30)$. The fact that the anti-TNF treatment has greater effects in the early phases of tumor growth as compared to late strongly suggests that TNF is not the only mediator involved in cachexia. The effects exerted by the anti-TNF antibodies administration, in particular the delaying of the decrease in insulin and increase in corticosterone plasmatic levels (cf 15), also support the idea that this cytokine may be important during the first days after tumor transplantation, probably altering the hormonal homeostasis towards a catabolic pattern.

The present observations strongly support an involvement of TNF in the development of cancer cachexia and, in particular, a role for this cytokine in mediating the alterations of protein metabolism. This is in keeping with previous reports on rats transplanted with a methylcholanthrene-induced sarcoma and rendered tolerant to TNF through repeated administrations of low doses of the cytokine (31) or on mice bearing the sarcoma MCG-101 treated with anti-TNF antibodies (32). Of interest, in the latter model, tumor cells themselves produced the cytokine, yet cachexia developed without any measurable plasma TNF (33), suggesting that this mediator might be important even at concentrations below the present levels of detectability.

A role for TNF in altering tissue protein metabolism has been suggested by a number of reports. Thus, a single dose of recombinant human TNF to rats resulted in increased muscle proteolysis (10), while rats given the cytokine on a chronic schedule lose total body protein at rates higher than pair-fed controls (7). TNF administration augmented the amino acid 
release from peripheral tissues in cancer patients (9), and muscle protein degradation was accelerated by TNF given at doses smaller than those required to produce hemodynamic changes (34). In vitro work also seems to implicate TNF in enhancing protein degradation (12), although evidence for its direct mediation of this effect remains elusive $(11,35,36)$. In the liver, TNF is able to enhance protein synthesis (37), to increase the proportion of mRNA species for serum albumin and acute phase proteins (38), and to stimulate the uptake of $\alpha$-aminoisobutyrate, a nonmetabolizable analogue of alanine (39).

It has been suggested that TNF may accelerate muscle protein catabolism by stimulating the release of adrenocortical hormones or interacting with them $(40,41)$. Such a possibility is compatible with the high levels of corticosterone occurring in rats bearing the Yoshida AH-130 hepatoma (15), as well as with their reduction on anti-TNF treatment, as shown by the present data. The same possibility applies to insulin, which markedly decreased in tumor bearers and was partially or totally restored to normal levels by the anti-TNF treatment. In this regard, the concurrent administration of insulin with TNF was shown to modulate the toxic effects of TNF on rats (27). In principle, an improvement in the nutritional state of tumor hosts could have been a predictable consequence of the antiTNF treatment, yet the food intake in anti-TNF-treated animals was not increased with respect to untreated or nonimmune IgG-treated experimental groups, thus ruling out this possible explanation for the anti-TNF effects. This finding provides further support to the view, derived from our previous work, that decreased food intake is unlikely to play a primary role in the development of cachexia in AH-130 tumor hosts (15). The only exception was the heart, wherein protein loss in tumor bearers was comparable to that in pair-fed controls (14).

The results presented here definitely implicate TNF in the changes of protein metabolism associated with the growth of the Yoshida AH-130 hepatoma. However, in these as well as in other experiments (Carbò, N., P. Costelli, L. Tessitore, G. J. Bagby, F. J. Lopez-Soriano, and J. M. Argilés, manuscript submitted for publication) the anti-TNF treatment was far from affording a complete protection, not even in the initial phases of tumor growth. Other humoral factors have been postulated to concur in mediating cancer cachexia in other models. Among the most recent reports, severe cachexia is induced by a muscle proteolytic factor produced by the murine colon adenocarcinoma MAC $16(42)$ or develops in nude mice implanted with different melanoma cell lines producing the leukemia inhibitory factor (43) or with Chinese hamster ovary cells transfected with human IFN- $\gamma$ cDNA (44). Moreover, Matthys et al. (45) have observed that the development of cachexia in mice bearing the Lewis lung carcinoma can be prevented by the administration of anti-IFN- $\gamma$ antibodies. Therefore, the present observations by no means can lead to the conclusion that TNF is the sole mediator of cancer cachexia, not even in the present model system.

\section{Acknowledgments}

Work supported by grants from the Fondo de Investigaciones Sanitarias de la Seguridad Social $(90 / 663)$ of the Spanish Health Ministry, the Direccíon General de Investigation Scientifica Y Tecnica (PB90-0497) from the Spanish Ministry of Education and Science, the Ministero dell'Università e della Ricerca Scientifica e Tecnologica (Roma), the Consiglio Nazionale delle Ricerche (Special Project A.C.R.O., Roma), the Associazione Italiana per la Ricerca sul Cancro (Milano), and Dr. Bagby's research on antibodies against TNF: the National Institutes of Health grant GM32654 (Bethesda, MD). N. Carbó is recipient of a predoctoral scholarship from the Centre Interdepartamental de Recerca $\mathrm{i}$ Innovaciò Tecnològica, Generalitat de Catalunya. P. Costelli is a recipient of a fellowship from the Fondazione A. Bossolasco (Torino).

\section{References}

1. Strain, A. J. 1979. Cancer cachexia in man: a review. Invest. \& Cell Pathol. 2:181-193.

2. Theologides, A. 1979. Cancer cachexia. Cancer (Phila.). 43:2004-2012.

3. Lawson, D. H., A. Richmond, D. W. Nixon, and D. Rudman. 1982. Metabolic approaches to cancer cachexia. Annu. Rev. Nutr. 2:227-301.

4. Evans, R. D., J. M. Argilés, and D. H. Williamson. 1989. Metabolic effects of tumour necrosis factor- $\alpha$ (cachectin) and interleukin-1. Clin. Sci. 77:357-364.

5. Beutler, B., and A. Cerami. 1986. Cachectin and tumour necrosis factor as two sides of the same biological coin. Nature (Lond.). 320:584-588.

6. Old, L. J. 1987. Polypeptide mediate network. Nature (Lond.). 326:330331.

7. Tracey, K. L., H. Wei, K. Manogue, Y. Fong, D. G. Hesse, H. T. Nguyen, G. C. Kuo, B. Beutler, R. S. Cotran, A. Cerami, and S. F. Lowry. 1988. Cachectin/tumor necrosis factor induces cachexia, anemia, and inflammation. J. Exp. Med. 167:1211-1227.

8. Fong, Y., L. L. Moldawer, M. Morano, H. Wei, A. Barber, K. Manogue, K. J. Tracey, G. Kuo, D. A. Fischman, A. Cerami, and S. F. Lowry. 1989. Cachectin/TNF or IL-1 alpha induces cachexia with redistribution of body proteins. Am. J. Physiol. 256:R659-R665.

9. Warren, R. S., H. F. Starnes, J. L. Gabrilove, H. F. Oettgen, and M. F. Brennan. 1987. The acute metabolic effects of tumor necrosis factor administration to humans. Arch. Surg. 122:1396-1400.

10. Flores, E. A., B. R. Bistrian, J. J. Pomposelli, C. A. Dinarello, G. L. Blackburn, and N. W. Istfan. 1989. Infusion of tumor necrosis factor/cachectin promotes muscle catabolism in rats. J. Clin. Invest. 83:1614-1622.

11. Kettlehut, I. C., and A. L. Goldberg. 1988. Tumor necrosis factor can induce fever in rats without activating protein breakdown in muscle or lipolysis in adipose tissue. J. Clin. Invest. 81:1384-1389.

12. Goodman, M. N. 1991. Tumor necrosis factor induces skeletal muscle protein breakdown in rats. Am. J. Physiol. 260:19-24.

13. Tessitore, L., G. Bonelli, and F. M. Baccino. 1987. Early development of protein metabolic perturbations in the liver and skeletal muscle of tumour-bearing rats. Biochem. J. 241:153-159.

14. Tessitore, L., P. Costelli, G. Bonetti, and F. M. Baccino. 1993. Cancer cachexia, malnutrition, and tissue protein turnover in experimental animals. Arch. Biochem. Biophys. In press.

15. Tessitore, L., P. Costelli, and F. M. Baccino. 1993. Humoral mediation for cachexia in tumour-bearing rats. Br. J. Cancer. 67:15-23.

16. Bagby, G. J., K. L. Plessala, L. A. Wilson, J. J. Thompson, and S. Nelson. 1991. Divergent efficacy of anti-TNF antibody in intravascular and peritonitis model of sepsis. J. Infect. Dis. 163:83-88.

17. Flick, D. A., and G. E. Gifford. 1984. Comparison of in vitro cell cytotoxic assay for tumor necrosis factor. J. Immunol. Methods. 68:167-175.

18. Lowry, O., N. J. Rosebrough, A. L. Farr, and R. J. Randall. 1951. Protein measurement with the Folin phenol reagent. J. Biol. Chem. 193:265-275.

19. Amenta, J. S., M. J. Sargus, and F. M. Baccino. 1978. Inhibition of basal protein degradation in rat embryo fibroblasts by cycloheximide: correlation with activities of lysosomal proteases. J. Cell. Physiol. 97:267-284.

20. Baccino, F. M., L. Tessitore, G. Cecchini, M. Messina, M. F. Zuretti, G. Bonelli, L. Gabriel, and J. S. Amenta. 1982. Control of cell protein catabolism in rat liver. Effects of starvation and administration of cycloheximide. Biochem. J. 206:395-406.

21. Swick, R. W., and M. M. Ip. 1974. Measurement of protein turnover in rat liver with $\left[{ }^{14} \mathrm{C}\right]$ carbonate. Protein turnover during liver regeneration. J. Biol. Chem. 249:6836-6841.

22. MacDonald, M. L., S. L. Augustine, T. L. Burck, and R. W. Swick. 1979. A comparison of methods for the measurement of protein turnover in vitro. Biochem. J. 184:473-476.

23. Garlick, P. J., M. A. McNurlan, and V. R. Preedy. 1980. A rapid and convenient technique for measuring the rate of protein synthesis in tissues by injection of $\left[{ }^{3} \mathrm{H}\right]$ phenylalanine. Biochem. J. 192:719-723.

24. Mahony, S. M., and M. J. Tisdale. 1988. Induction of weight loss and metabolic alterations by human recombinant tumour necrosis factor. $\mathrm{Br}$. $J$. Cancer. 58:345-349.

25. Argilés, J. M., C. Garcìa-Martinez, M. Llovera, and F. J. Lopez-Soriano. 1992. The role of cytokines in host wasting: its relation with cancer cachexia. Med. Res. Rev. 12:637-652.

26. Selby, P., S. Hobbs, C. Viner, E. Jackson, A. Jones, D. Newell, A. H. 
Calvert, T. McElwain, K. Fearon, J. Humpherys, and T. Shiga. 1987. Tumour necrosis factor in man: clinical and biological observations. Br. J. Cancer. 56:803-808.

27. Fraker, D. L., B. C. Sheppard, and J. A. Norton. 1990. Impact of tolerance of antitumor efficacy of tumor necrosis factor in mice. Cancer Res. 50:22612267.

28. Oliff, A., D. Defeo-Jones, M. Boyer, D. Martinez, D. Kiefer, G. Vuocolo, A. Wolfe, and S. H. Socher. 1987. Tumors secreting human TNF/cachectin induce cachexia in mice. Cell. 50:555-563.

29. Beck, S. A., K. L. Smith, and M. J. Tisdale. 1991. Anticachectic and antitumour effect of eicosapentenoic acid and its effect on protein turnover. Cancer Res. 51:6089-6093.

30. Darling, G., D. L. Fraker, C. J. Jensen, C. M. Gorschboth, and J. A. Norton. 1990. Cachectic effects of recombinant human tumor necrosis factor in rats. Cancer Res. 50:4008-4013.

31. Sheppard, B. C., D. Venzon, D. L. Fraker, H. N. Langstein, C. J. Jensen, and J. A. Norton. 1990. Prolonged survival of tumor-bearing rats with repetitive low dose recombinant tumor necrosis factor. Cancer Res. 50:3928-3933.

32. Sherry, B. A., J. Gelin, Y. Fong, M. Marano, H. Wei, A. Cerami, S. F. Lowry, K. Lundholm, and L. L. Moldawer. 1989. Anticachectin tumor necrosis factor- $\alpha$ antibodies attenuate development of cachexia in tumor model. FASEB (Fed. Am. Soc. Exp. Biol.) J. 3:1956-1962.

33. Gelin, J., L. L. Moldawer, C. Lönnroth, B. Sherry, R. Chizzonite, and K. Lundholm. 1991. Role of endogenous tumor necrosis factor- $\alpha$ and interleukin-1 for experimental tumor growth and the development of cancer cachexia. Cancer Res. 51:415-421.

34. Pomposelli, J. J., E. A. Flores, and B. R. Bistrian. 1988. The role of biochemical mediators in clinical nutrition and surgical metabolism. J. Parenter. Enteral Nutr. 12:212-219.

35. Moldawer, L. L., G. Svaninger, J. Gelin, and K. G. Lundholm. 1987. Interleukin-1 and tumor necrosis factor do not regulate protein balance in skeletal muscle. Am. J. Physiol. 253:C766-C773.
36. Goldberg, A. L., I. C. Kettlehut, K. Furuno, J. M. Fagan, and V. E. Baracos. 1988. Activation of protein breakdown and prostaglandin $E_{2}$ production in rat skeletal muscle in fever is signaled by a macrophage product distinct from interleukin-1 or other known monokines. J. Clin. Invest. 81:1378-1383.

37. Charters, Y., and R. F. Grimble. 1989. Effect of recombinant human tumour necrosis factor $\alpha$ on protein synthesis in liver, skeletal muscle and skin of rats. Biochem. J. 258:493-497.

38. Perlmutter, D. H., C. A. Dinarello, P. J. Punsal, and H. R. Colten. 1986. Cachectin/tumor necrosis factor regulates hepatic acute phase gene expression. J. Clin. Invest. 78:1349-1354.

39. Argilés, J. M., F. J. Lopez-Soriano, D. Wiggins, and D. H. Williamson. 1989. Comparative effects of tumour necrosis factor- $\alpha$ (cachectin), interleukin$1-\beta$ and tumour growth on amino acid metabolism in the rat in vivo. Biochem. $J$. 261:357-362.

40. Mealy, K. J. J. B. VanLaschot, B. G. Robinson, J. Rounds, and D. W. Wilmore. 1990. Are the catabolic effects of tumor necrosis factor mediated by glucocorticoids? Arch. Surg. 125:42-48.

41. Hall-Angeras, M., U. Angeras, O. Zamir, P. O. Hasselgren, and J. F. Fisher. 1990. Interaction between corticosterone and tumor necrosis factor stimulated protein breakdown in rat skeletal muscle, similar to sepsis. Surgery (St. Louis) 108:460-466.

42. Tisdale, M. J. 1990. Newly identified factors that alter host metabolism in cancer cachexia. Trends Pharmacol. Sci. 11:473-475.

43. Mori, M., K. Yamaguchi, S. Honda, K. Nagasaki, M. Ueda, O. Abe, and K. Abe. 1991. Cancer cachexia syndrome developed in nude mice bearing melanoma cells producing leukemia-inhibitory factor. Cancer Res. 51:6656-6659.

44. Matthys, P., R. Dukmans, P. Proost, J. VanDamme, H. Heremans, H. Sobis, and A. Billiau. 1991. Severe cachexia in mice inoculated with interferon- $\gamma$ producing tumor cells. Int. J. Cancer. 49:77-82.

45. Matthys, P., H. Heremans, G. Opdenakker, and A. Billiau. 1991. Anti-interferon- $\gamma$ antibody treatment, growth of Lewis lung tumours in mice and tumour associated cachexia. Eur. J. Cancer. 27:182-187. 